\title{
INKLUSIVISME GURU PENDIDIKAN AGAMA ISLAM (Studi atas Pandangan Guru PAI tentang Konsep Tasamuh di SMK NU Lamongan, Mts Putra Putri Lamongan, SD NU Banat-Banin Lamongan)
}

\author{
A. Samsul Ma'arif \\ UIN Maulana Malik Ibrahim Malang \\ syamsulsyafa@uin-malang.ac.id
}

Article History:

Received : 05-06-2019

Revised : 21- 08-2019

Accepted : 05-09-2019

\begin{abstract}
Educational institutions in which there is an educational process, have a function not only in the aspect of developing science, but also have a mission to improve the quality of personality through good character. In this position, the teacher has a role in instilling inclusive values (tasamuh) in the learning process that can be applied in everyday life as well as the process in developing the potential of their students. Each educational institution or each teacher will have different tasamuh values in each habituation or teaching. Get used to communicating with others using the language of unity, namely Indonesian, helping each other, not blaming others, especially fellow Muslims, especially other religions, and respecting different principles and respecting others. This study focuses on the views of Islamic Education teachers about the concept of tasamuh and the actualization of the tasamuh attitude of Islamic Education teachers in the learning process at SMK NU Lamongan, MTs Putra Putri Lamongan, SD NU Banat-Banin Lamongan. This study uses a qualitative research method with a phenomenological approach. This study shows that teachers play a role in developing tolerant attitudes to students in the school environment, social groups and even the community, through habituation and learning Islamic Education. The teacher's perspective on inclusive attitudes also plays a role in shaping the personality of students to be more open and respect all differences.
\end{abstract}

Keywords: inclusivism, Islamic Education, teacher

\section{Pendahuluan}

Islam adalah "Rahmatan lil 'alamin" yaitu sebagai pembawa berkah/rahmat bagi alam semesta, islam sebagai agama "Rahmatan lil 'alamin" harus bisa membawa berkah/rahmat bagi seluruh umat manusia, dalam hal ini memang umat islam haruslah bisa berbuat baik kepada siapaun tanpa terkecuali. Dunia ini terdiri dari berbagai negara, bangsa, suku, dan tentunya dengan berbagai karakter manusia. Kerukunan antar umat, bangsa, dan negara tidak akan terwujud tanpa nilai toleransi atau tasamuh yang dimiliki oleh manusia. 
Dengan begitu tasamuh merupakan sikap menerima perbedaan dan tidak mendiskriminasi terhadap kelompok yang berbeda. Sikap toleransi ini harus didasari sikap kelapangan dada terhadap orang lain dengan memperhatikan prinsip-prinsip yang dipegang sendiri, yakni tanpa mengorbankan prinsip-prinsip tersebut. Jelas bahwa toleransi terjadi dan berlaku karena terdapat perbedaan prinsip, dan menghormati perbedaan atau prinsip orang lain tanpa mengorbankan prinsip sendiri. ${ }^{1}$ Sangat penting toleransi itu karena kita hidup di dunia tidak hanya satu agama, bermacam-macam agama jadi tetap diperlukan toleransi itu. Segala muamalah diperbolehkan toleransi itu kecuali satu yakni dalam hal ibadah. ${ }^{2}$

Menurut Undang-Undang No. 20 Tahun 2003 tentang SISDIKNAS Bab I mengatakan "Pendidikan adalah usaha sadar dan terencana untuk mewujudkan suasana belajar dan proses pembelajaran agar peserta didik secara aktif mengembangkan potensi dirinya untuk memiliki kekuatan spiritual keagamaan, pengendalian diri, kepribadian, kecerdasan, akhlak mulia, serta keterampilan yang diperlukan bagi dirinya, masyarakat, bangsa dan negara". ${ }^{3}$

Jadi sekolah atau lembaga pendidikan disini berperan untuk menanamkan nilainilai positif dalam perubahan akhlak baik dalam pembiasaaan atau pembelajaran yang dapat diterapkan dalam kehidupan sehari-hari serta proses dalam mengembangkan potensi dirinya.

Tiap lembaga pendidikan atau masing-masing guru akan memiliki nilai-nilai tasamuh yang berbeda dalam tiap pembiasaan atau pengajaran. Membiasakan komunikasi dengan yang lain menggunakan bahasa persatuan yakni bahasa indonesia, saling tolong menolong, tidak menyalahkan orang lain, tidak membid'ah-bid'ah kan, tidak mengkafir-kafirkan islam lain atau agama lain, atau menghargai prinsip berbeda dan menghormati sesama.

Berdasarkan uraian tersebut pandangan mengenai tasamuh juga aktualisasi sikap tasamuh dalam pembelajaran di SMK NU Lamongan, MTs Putra Putri Lamongan, SD NU Banat-Banin Lamongan akan berbeda. Aktivitas utama dalam penelitian ini yaitu menganalisa pandangan guru PAI di SMK NU Lamongan, MTs Putra Putri Lamongan dan SD NU Banat-Banin Lamongan tentang konsep tasamuh serta aktualisasi sikap tasamuh dalam proses pembelajaran dengan metode penelitian kualitatif dan pendekatan fenomenologi. Metode penelitian kualitatif sering disebut metode penelitian naturalistik karena penelitiannya dilakukan pada kondisi yang alamiah (natural setting). ${ }^{4}$ Fokus perhatian fenomenologi tidak hanya sekedar fenomena, akan tetapi pengalaman sadar dari sudut pandang orang pertama atau yang mengalaminya secara langsung. ${ }^{5}$

${ }^{1}$ Said Agil Husin Al-Munawar, Fikih Hubungan Antar Agama, (Jakarta: PT Ciputat Press, 2005), 13.

2 Chusnul Chotimah, Wawancara, lamongan, 17 Desember 2019.

3 Undang-Undang Republik Indonesia Nomor 20 Tahun 2003, Pasal 1, Ayat 1, Tentang Sistem Pendidikan Nasional.

${ }^{4}$ Sugiono, Metode Penelitian Kuantitatif Kualitatif dan R\&D (Bandung : Alfabeta, 2011), 8

5 Engkus Kuswarno, Fenomenologi:Metodologi Penelitian Komunikasi (Bandung: Widya Padjajaran, 2009), 22. 
Pengumpulan data dalam penelitian ini menggunakan cara Observasi dengan mengumpulkan data aktualisasi sikap tasamuh guru PAI dalam proses pembelajaran, lalu metode Wawancara untuk memperoleh data pandangan guru PAI tentang konsep tasamuh dan aktualisasi sikap tasamuh guru PAI dalam proses pembelajaran, dan Dokumentasi untuk mengumpulkan data identitas masing-masing sekolah. Adapun teknik analisis data yaitu Reduksi data yaitu proses pemilihan, pemusatan perhatian pada penyederhanaan, pengabstrakan, transformasi data kasar yang muncul dari catatan-catatan lapangan. ${ }^{6}$ Display data yaitu rakitan kalimat yang disusun secara logis dan sistematis, dan Verifikasi yaitu suatu cara untuk berusaha mencari kesimpulan dari permasalahan yang diteliti.

\section{Konsep Inklusivisme (tasammuh) dalam Islam}

Pandangan setiap guru mengenai konsep tasamuh berbeda, dan menanamkan nilai-nilai tasamuh dengan baik melalui pembiasaan maupun pembelajaran di SMK NU Lamongan, MTs Putra Putri Lamongan, dan SD NU Banat-Banin Lamongan.

Islam adalah "Rahmatan lil 'alamin" yaitu sebagai pembawa berkah/rahmat bagi alam semesta, Islam sebagai agama "Rahmatan lil 'alamin" harus bisa membawa berkah/rahmat bagi seluruh umat manusia, dalam hal ini memang umat Islam haruslah bisa berbuat baik kepada siapaun tanpa terkecuali. Dunia ini terdiri dari berbagai negara, bangsa, suku, dan tentunya dengan berbagai karakter manusia. Kerukunan antar umat, bangsa, dan negara tidak akan terwujud tanpa nilai toleransi atau tasamuh yang dimiliki oleh manusia.

Inklusivisme yaitu anggapan kebenaran yang hanya terdapat didalam agama sendiri, tetapi juga mengakui bahwa tidak ada kebenaran yang absolut yang betul-betul benar sehingga semua agama kelihatannya menuju kebenaran absolut. ${ }^{7}$

Begitupun menurut pandangan guru pendidikan agama Islam di MTs Putra Putri Lamongan, tiap individu berhak atas kepercayaan dan agama masing-masing, melakukan ibadah sesuai dengan ajaran agama masing-masing. Setiap umat beragama penting memiliki nilai toleransi dalam dirinya, menghargai dan tidak mengkafir-kafirkan agama lain. Dalil toleransi dalam al-Qur'an :

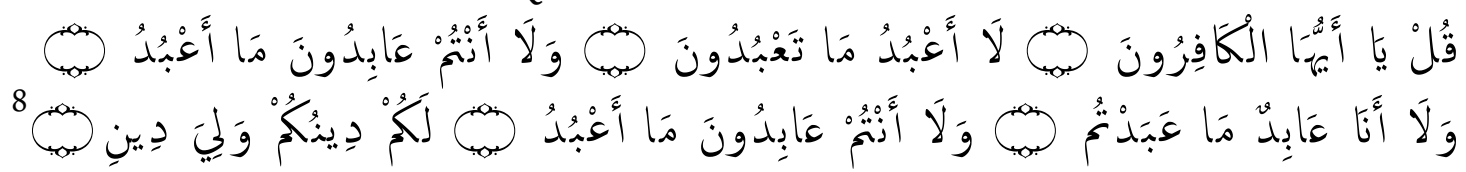

"Katakanlah: "Hai orang-orang kafir, Aku tidak akan menyembah apa yang kamu sembah. Dan kamu bukan penyembah Tuhan yang aku sembah. Dan aku tidak pernah menjadi

${ }^{6}$ Metther B. Milies and A. Michael Hubermen, Qualitative Data Analysis (London: Sage Publication, 1984), 16.

${ }^{7}$ Hilyatul Aulia, "Inklusivisme Menurut Masyarakat Muslim Dan Kristen Dusun Gendeng Kel. Baciro Kec. Gondokusuman Kota Yogyakarta” (Skripsi-Universitas Islam Negeri Sunan Kalijaga Yogyakarta, 2017), 11.

${ }^{8}$ Al-Qur'an 109 : 1-6 
penyembah apa yang kamu sembah, dan kamu tidak pernah (pula) menjadi penyembah Tuhan yang aku sembah. Untukmu agamamu, dan untukkulah, agamaku"."9

Baidi Bukhori menyatakan bahwa tasamuh (toleransi) adalah pendirian atau sikap yang termanifestasikan pada kesediaan untuk menerima berbagai pandangan dan pendirian yang beranekaragam, meskipun tidak sependapat dengannya. Lebih lanjut dijelaskan bahwa toleransi ini erat kaitannya dengan masalah kebebasan atau kemerdekaan hak asasi manusia dalam tata kehidupan bermasyarakat, sehingga mengizinkan berlapang dada terhadap adanya perbedaan pendapat dan keyakinan dari setiap individu. ${ }^{10}$

Menurut pandangan guru SMK NU Lamongan, tidak membid'ah-bid'ah kan dan mengkafir-kafirkan agama lain maupun perbedaan amaliyah-amaliyah orang lain atau perbedaan pandangan keislaman mewujudkan kehidupan beragama yang rukun dan damai.

Kerukunan antar umat beragama tidak akan terwujud tanpa adanya sikap toleransi. Tak perlu menjadikan segala perbedan atau keragaman ini menjadi suatu konflik karena pada hakikatnya manusia adalah masyarakat yang majemuk dan beragam. Dan keberagaman tersebut adalah sebuah keniscayaan yang harus dengan sadar diterima. Allah telah menciptakan agama yang berbeda-beda dan dengan keragaman tersebut agar manusia mampu berikhtiar mencari kebenaran. Dan kebenaran mutlak sesungguhnya hanya milik Allah. Sebagaimana dijelaskan oleh Allah dalam firman-Nya :

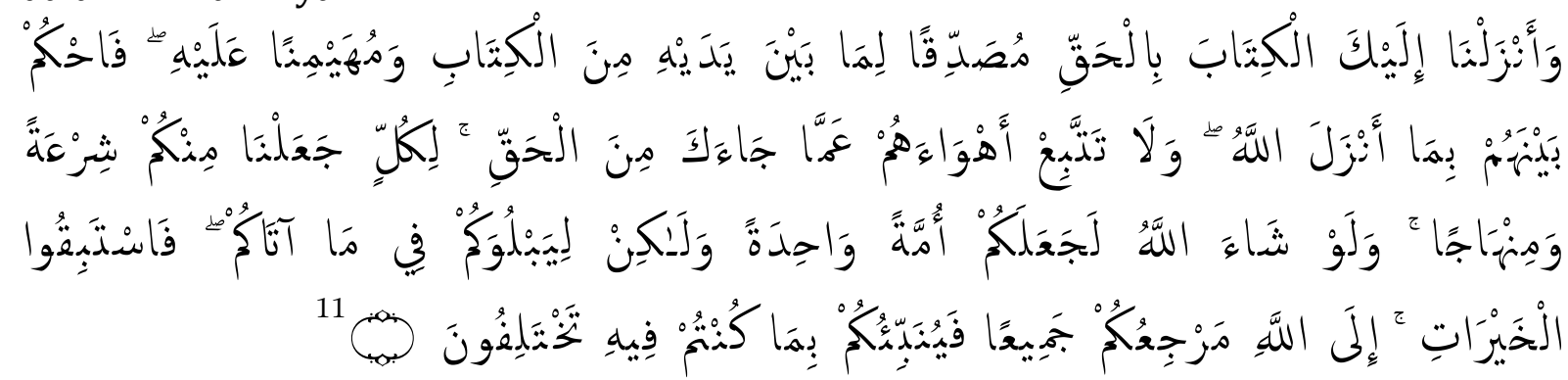

"Dan Kami telah turunkan kepadamu Al Quran dengan membawa kebenaran, membenarkan apa yang sebelumnya, yaitu kitab-kitab (yang diturunkan sebelumnya) dan batu ujian terhadap kitab-kitab yang lain itu; maka putuskanlah perkara mereka menurut apa yang Allah turunkan dan janganlah kamu mengikuti hawa nafsu mereka dengan meninggalkan kebenaran yang telah datang kepadamu. Untuk tiap-tiap umat diantara kamu, Kami berikan aturan dan jalan yang terang. Sekiranya Allah menghendaki, niscaya kamu dijadikan-Nya satu umat (saja), tetapi Allah hendak menguji kamu terhadap pemberian-Nya kepadamu, maka berlomba-lombalah berbuat kebajikan. Hanya kepada

\footnotetext{
${ }^{9}$ Kementrian Agama RI, Al-Qur'an dan Terjemahnya

10 Baidi Bukhori, Toleransi terhadap Umat Kristiani Ditinjau dari Fundamentalisme Agama dan Kontrol Diri (Semarang: IAIN Walisongo Semarang. 2012), 15

${ }^{11}$ Al-Qur'an $5: 48$

P-ISSN(2549-7987); E-ISSN (2550-0341)

A. Samsul Ma'arif| 327
} 
Allah-lah kembali kamu semuanya, lalu diberitahukan-Nya kepadamu apa yang telah kamu perselisihkan itu."12

Dalam hal ini pandangan guru SMK NU Lamongan, negara Islam tidak bisa diterapkan di negara majemuk, perbedaan sebagai pemersatu yang harus dipegang teguh asal tidak bersebrangan yang menjadikan perpecahan bangsa.

Dan pandangan guru MTs Putra Putri Lamongan menerima atau mengizinkan pada tiap individu untuk beribadah sesuai keyakinan dan madzab yang benar untuk dianut. Islam terkhusus di Indonesia agama ini diakulturasikan agar mampu diterima dengan baik, dan akuntasi budaya tidak ada yang menyalahi norma/batas agama Islam sendiri.

Begitupula menurut pandangan guru SD NU Banat-Banin Lamongan pandangan Islam dalam konsep berpikir Ahlussunnah Wal Jama'ah yakni tasamuh bahwasannya setiap jenis kelamin atau golongan itu harus saling menghormati satu sama lain agar tidak terjadi kesalahpahaman atau perpecahan.

Emile Durkheim mengatakan agama sebagai solidaritas masyarakat. Solidaritas sosial adalah kesetiakawanan yang merujuk pada suatu keadaan hubungan antara individu atau kelompok yang didasarkan pada perasaaan moral dan kepercayaan yang dianut bersama yang diperkuat oleh pengalaman emosional bersama. Dengan solidaritas yang dibangun dalam sebuah masyarakat maka segala kepentingan individu akan melebur menjadi sebuah tatanan kehidupan sosial yang harmonis walaupun dalam hal teologi dan ideologi mereka mempunyai pendapat tersendiri. ${ }^{13}$

Pandangan guru SMK NU Lamongan tanpa solidaritas, Perpecahan dan adu domba terjadi sebab diskriminasi minoritas yang dilakukan atas kepentingan individu. Maka dari itu sikap kelapangan dada terhadap orang lain perlu tanpa mengorbankan keyakinan, melaksanakan ibadah dan akidah sesuai keyakinan tiap individu.

Menurut pandangan guru MTs Putra Putri Lamongan solidaritas ini masih kurang sehingga diskriminasi minoritas menjadi masalah sebab bangsa Indonesia belum benarbenar menjadikan pancasila sebagai landasan hidup.

Namun solidaritas sosial dalam pandangan guru PAI SD NU Banat-Banin Lamongan yakni sikap tasamuh atau toleransi yang dimiliki oleh manusia untuk mewujudkan kehidupan yang rukun dan damai dengan menerima, menghargai setiap perbedaan yang ada juga menyadari perbedaan sebagai rahmat juga kemaslahatan bagi umat manusia. Karena sesungguhnya semua ciptaan Allah sama yang membedakan hanyalah ketakwaanya. Seperti firman-Nya :

12 Kementrian Agama RI, Al-Qur'an dan Terjemahnya

13 Hilyatul Aulia, "Inklusivisme Menurut Masyarakat Muslim Dan Kristen”, 11. 


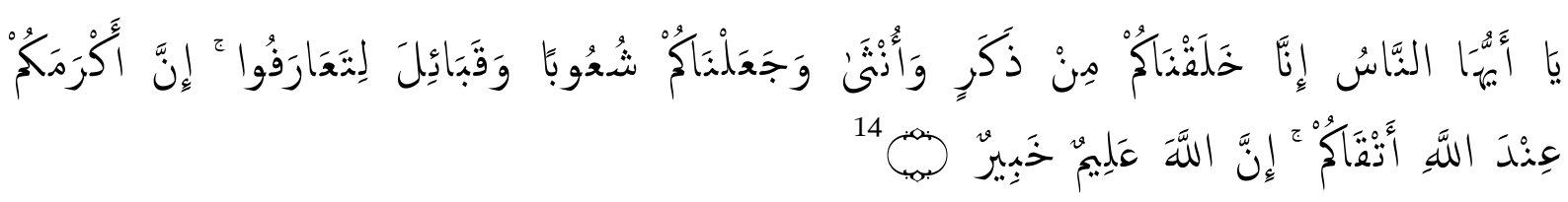

"Hai manusia, sesungguhnya Kami menciptakan kamu dari seorang laki-laki dan seorang perempuan dan menjadikan kamu berbangsa-bangsa dan bersuku-suku supaya kamu saling kenal-mengenal. Sesungguhnya orang yang paling mulia diantara kamu disisi Allah ialah orang yang paling takwa diantara kamu. Sesungguhnya Allah Maha Mengetahui lagi Maha Mengenal."15

Tasamuh dalam ajaran Islam memiliki batasan atau aturan yang jelas, seperti dalam hal pelaksanaan ibadah dan akidah. Namun dalam aspek sosial kemasyarakatan, seperti bergaul, bertetangga, berdagang, dan aktifitas sosial (keduniawian) lainnya diperbolehkan. Dengan demikian dalam bertoleransi memiliki rambu-rambu yang harus dipatuhi yaitu mengakui hak setiap orang, menghormati keyakinan orang lain, lapang dada menerima perbedaan, saling pengertian, kesadaran dan kejujuran. ${ }^{16}$ Begitupun pandangan guru MTs Putra Putri Lamongan, sikap toleransi penting dalam kehidupan sosial dalam segala hal dan muamalah kecuali satu yakni dalam hal ibadah.

\section{Artikulasi sikap tasamuh guru PAI dalam proses pembelajaran di SMK NU Lamongan, MTs Putra Putri Lamongan, dan SD NU Banat-Banin Lamongan.}

Pendidikan toleransi adalah sebuah niscaya dalam kehidupan yang begitu jamak. Membumikan nilai toleransi dalam segala bentuk aktivitas sosial menjadi satu hal yang mesti ditunaikan dengan sedemikian konkret dan praktis. Setiap yang berbeda dalam kehidupan agar tidak melahirkan konflik tertentu kemudian harus dijubahi dengan nilai toleransi. ${ }^{17}$ Jadi, pendidikan tasamuh adalah sikap usaha sadar dalam memberikan bimbingan dan pengarahan kepada anak didik agar bisa bersikap menerima perbedaan.

Pribadi yang memiliki toleransi adalah pribadi yang toleran. Orang yang memiliki toleransi dalam dirinya akan melihat perbedaan tidak sebagai pertentangan apalagi permusuhan, sebab perbedaan adalah rahmat. Pribadi yang toleran mampu menerima, menghargai, dan memberi kebebasan kelompok lain baik yang sama maupun berbeda. Juga memliki kesabaran dan mampu bekerja sama dengan yang lain. Beberapa aspek tasamuh sebagai berikut:

1. Penerimaan

Kunci dari tasamuh adalah menerima orang apa adanya. Adanya kesediaan seseorang untuk menerima pendapat, nilai-nilai, perilaku orang lain yang berbeda dari

14 Al-Qur'an $49: 13$

15 Kementrian Agama RI, Al-Qur'an dan Terjemahnya

16 Ninik Yusrotul Ula, "Konsep Pendidikan Tasamuh dalam Mewujudkan Islam Rahmatan lil 'alamin di Pondok Pesantren Tebuireng Jombang” (Skripsi-- Universitas Islam Negeri Maulana Malik Ibrahim Malang, 2017), 20.

17 Ninik Yusrotul Ula, “Konsep Pendidikan Tasamuh",28. 
diri sendiri. Penerimaan dapat diartikan memandang dan menerima pihak lain dengan segala keberadaannya, dan bukan menurut kehendak dan kemauannya sendiri, tanpa memperhitungkan perbedaan, kelebihan atau kekurangan. ${ }^{18}$

Seorang guru harus mampu berperan dihadapan siswa yang berbeda, memberikan bimbingan dan pengarahan sehingga di antara siswa tersebut pun mampu bersikap toleran atau meneima perbedaan.

Setiap guru baik di SMK NU Lamongan, MTs Putra Putri Lamongan, dan SD NU Banat-Banin Lamongan senantiasa menerima segala perbedaan para peserta didiknya, baik dari latar belakang keluarga, tempat tinggal, ekonomi, latar belakang pendidikan, karakter maupun intelligence.

2. Penghargaan

Selain kesediaan menerima, hal penting lain yang terkait dengan toleransi adalah kesediaan untuk menghargai segala sesuatu yang ditolak atau ditentang oleh seseorang. Menghormati keyakinan seseorang, karena keyakinan adalah urusan pribadi masingmasing orang. Tiap-tiap umat beragama harus menghormati eksistensi agama lain dengan cara menghormati keragaman dan perbedaan ajaran-ajaran yang terdapat pada setiap agama dan kepercayaan yang ada baik yang diakui negara maupun yang belum diakui oleh negara. ${ }^{19}$

Dengan perbedaan lulusan di SMK NU Lamongan dari yang lulusan MTs maupun SMP semua mendapat perlakuan yang sama rata. Peserta didik dengan lulusan MTs lebih muda memahami materi yang diajarkan sebab sudah memiliki modal dasar yang telah diperoleh, namun guru di SMK NU Lamongan selalu menghargai usaha yang telah dilakukan, tak pernah mendiskriminasi yang tak memenuhi capaian belajarnya,

Berbagai bentuk strategi guru dalam mengupayakan ketercapaian belajar siswa selalu dilakukan oleh guru MTs Putra Putri Lamongan dalam proses pembelajaran dengan berbagai karakter juga tingkat pemahaman peserta didik satu dengan lainnya yang berbeda. Guru senantiasa mengharagai segala perbedaan argument/pendapat para siswa, begitupun untuk siswa yang kurang tanggap dalam pemahaman materi yang diajarkan.

Perbedaan intelligence atau tingkat pemahaman siswa menjadi tantangan bagi seorang guru dalam mencapai capaian belajar di SD NU Banat-Banin Lamongan. Siswa senantiasa mendengarkan dan memperhatikan bagaimana guru mengajar. Terlepas itu guru bertanggung jawab atas sejauh mana pemahaman siswa dalam menangkap materi pembelajaran dengan memberikan pertanyaan maupun mendengarkan pertanyaan yang diajukan siswa. Dengan begitu guru dapat melihat seberapa jauh pemahaman siswa terhadap materi yang diajarkan, dan tugas guru mengajarkan juga mengarahkan hingga mencapai capaian belajarnya.

18 Baidi Bukhori, Toleransi terhadap Umat Kristiani, 18.

${ }^{19}$ Ibid., 19 


\section{Kesabaran}

Kesabaran merupakan suatu sikap simpatik terhadap perbedaan pandangan dan sikap orang lain. Kesabaran juga dapat diartikan sebagai kemampuan untuk menahan hal-hal yang tidak disetujui atau tidak disukai, dalam rangka membangun hubungan social yang lebih baik. Maka kita harus mempunyai sikap sabar dan menahan diri untuk tidak mengganggu dan tidak melecehkan agama atau sistem keyakinan dan ibadah penganut agama-agama lain. ${ }^{20}$

Bagi guru MTs Putra Putri Lamongan keprofesionalannya menjadi seorang guru melekat pada sifat utama yang harus dimiliki yakni sabar, dan menjaga wibawa menjadi seorang guru. Karena guru sebagai figure panutan untuk peserta didiknya. Sudah tugas guru mendidik, membimbing, mengarahkan peserta didiknya dengan sikap toleransi nya menghadapi peserta didiknya. Menerima, menghargai segala perbedaan peserta didiknya baik karakter maupun tingkat pemahamannya.

Latar belakang lulusan dan intelligence siswa menjadi PR bagi guru di SMK NU Lamongan. Siswa yang kurang dalam capaian belajarnya memerlukan penjelasan extra karena masih membutuhkan pemahaman yang sedikit lama. Dalam hal ini sudah tugas guru untuk memahamkan peserta didiknya juga mencapai capaian belajar. Terlepas dari itu salah satu strategi guru SMK NU Lamongan menghadapi hal tersebut yakni dengan remedial.

Dalam sikap toleransi terdapat kesabaran pada setiap guru di SD NU Banat-Banin Lamongan. Ditunjukkan pada bagaimana cara guru menghadapi tingkat pemahaman peserta didik yang berbeda, yang sulit menerima pelajaran, strategi guru SD NU BanatBanin Lamongan salah satunya yakni mengadakan kelas tambahan diluar jam pelajaran dengan maksud memahamkan peserta didik yang belum faham agar tidak tertinggal dengan yang lainnya.

4. Kebebasan

Memberi kebebasan kepada sesama manusia atau kepada sesama warga masyarakat untuk menjalankan keyakinannya atau mengatur hidupnya dan menentukan nasibnya masing-masing. Hak asasi manusia yang paling esensial dalam hidup adalah hak kemerdekaan/kebebasan baik kebebasan untuk berfikir maupun kebebasan untuk berkehendak dan kebebasan di dalam memilih kepercayaan/agama. Kebebasan merupakan hak yang fundamental bagi manusia sehingga hal ini yang dapat membedakan manusia dengan makhluk yang lainnya. ${ }^{21}$

Baik di SMK NU Lamongan, MTs Putra Putri Lamongan, dan SD NU Banat-Banin Lamongan peserta didik bebas dalam menyampaikan pendapatnya. Kebebasan berfikir menjadikan peserta didik berkembang dengan kemampuannya.

5. Kerjasama

Toleransi mempunyai sikap membiarkan dan tidak menyakiti orang atau kelompok lain baik yang berbeda maupun yang sama. Tapi kita juga membutuhkan

20 Ibid., 20

21 Ibid., 21 
bantuan dan dukungan terhadap keberadaan orang lain atau kelompok. Sehingga kita harus bersedia bekerjasama dengan pemeluk agama lain. ${ }^{22}$

Ada dua macam toleransi agama, yakni toleransi statis dan toleransi dinamis. Toleransi statis adalah toleransi dingin yang tidak melahirkan kerjasama. Bila pergaulan antar umat beragama hanya dalam bentuk statis, maka akan melahirkan toleransi semu. Toleransi dinamis adalah toleransi aktif yang melahirkan kerja sama untuk tujuan bersama, sehingga kerukunan antar umat beragama sebagai refleksi dari kebersamaan umat beragama sebagai satu bangsa. Dengan demikian dapat diperoleh pemahaman bahwa manifestasi dari toleransi agama adalah adanya kesediaan bekerjasama dengan pemeluk agama lain. ${ }^{23}$

Dalam hal ini semua guru di SMK NU Lamongan, MTs Putra Putri Lamongan maupun SD NU Banat-Banin Lamongan senantiasa membiasakan para peserta didiknya untuk selalu berteman dengan siapapun tanpa melilih, saling menjaga kekraban, tidak membeda-bedakan sehingga tidak ragu untuk saling tolong menolong dan bekerja sama dalam proses pembelajaran. Melalui pembiasaan menjadikan keadaan tersebut sebagai suatu kebiasaan yang tanpa disadari dilakukan peserta didik.

Menurut Tobroni dalam pemikiran Islam, secara bahasa maupun istilah, guru dalam Islam dapat dipahami sebagai orang-orang yang bertanggung jawab terhadap perkembangan anak didik. Guru pendidikan agama Islam adalah seorang pendidik yang mengajarkan Islam untuk mencapai keseimbangan jasmani maupun rohani untuk megubah tingkah laku individu sesuai dengan ajaran Islam dan membimbing anak didik kearah pencapaian kedewasaan serta membentuk kepribadian muslim yang berakhlak, sehingga terjadi keseimbangan kebahagiaan di dunia dan akhirat. ${ }^{24}$

Dengan demikian tasamuh dalam pendidikan Islam merupakan bagaimana seorang guru mampu berperan dihadapan siswa yang berbeda, memberikan bimbingan dan pengarahan sehingga di antara siswa tersebut pun mampu bersikap toleran atau meneima perbedaan.

Adapun penanaman konsep pendidikan tasamuh melalui pembiasaanpembiasaan yang dilakukan terhadap siswa, diartikulasikan oleh guru PAI melalui proses pembelajaran dengan berbagai metode yang dapat menumbuhkan sikap dan pemikiran yang toleran. Antara lain, diajak berdiskusi, berbeda pendapat, menyangga pernyataan dengan etika yang baik. Guru PAI, baik di SMK NU Lamongan, Mts PutraPutri Lamongan dan SD NU Banat-Banin Lamongan memberikan stimulus kepada peserta didik melalui pendapat-pendapat yang mereka tidak sependapat, lalu ditunjukan bagaimana adab dalam perbedaan pendapat (adab al-ikhtilaf). Melalui strategi ini, perspektif guru terhadap konsepsi toleransi (tasammuh) berperan pentingb dalam membangun konstruk berfikir dan bersikap peserta didik.

\footnotetext{
22 Ibid., 22

${ }^{23}$ Said Agil Husin Al-Munawar, Agenda Generasi Intelektual: Ikhtiar Membangun Masyarakat Madani (Jakarta: Pernamadani, 2003), 15.

24 Tobroni, Pendidikan Islam Paradigma Teologis, Filosofis dan Spiritualitas (Malang: UMM Press, 2008), 107 


\section{Kesimpulan}

Berdasarkan hasil penelitian, pandangan guru pendidikan agama Islam di SMK NU Lamongan, MTs Putra Putri Lamongan, dan SD NU Banat-Banin Lamongan mengenai konsep tasamuh yakni tidak membid'ah-bid'ah kan dan mengkafir-kafirkan agama lain maupun perbedaan pandangan keIslaman atau amaliyah-amaliyah orang lain. Memberikan kebebasan atas agama dan kepercayaan masing-masing serta melakukan ibadah sesuai ajaran agama masing-masing. Meneriman dan menghargai setiap perbedaan yang ada dengan menyadari perbedaan sebagai rahmat juga kemaslahatan bagi umat manusia. Karena sesungguhnya semua ciptaan Allah sama yang membedakan hanyalah ketakwaanya. Kerukunan antar umat beragama tidak akan terwujud tanpa adanya sikap toleransi. Aktualisasi sikap tasamuh guru PAI dalam proses pembelajaran di SMK NU Lamongan, MTs Putra Putri Lamongan, dan SD NU Banat-Banin Lamongan meliputi : Pertama Penerimaan, seorang guru mampu bersikap toleran dengan menerima perbedaan karakter dan intelligence yang ada pada peserta didiknya, dengan tugas utamanya yakni mendidik, mengajar, membimbing, mengarahkan, melatih, menilai, dan mengevaluasi peserta didik. Kedua, Penghargaan: menghargai dan menghormati segala perbedaan yang ada pada peserta didik, menghargai upaya peserta didik dalam proses pembelajaran. Ketiga, Kesabaran : sifat utama yang melekat pada setiap guru adalah sabar. Menerima, segala perbedaan karakter dan intelligence yang ada pada peserta didik, juga situasi yang dihadapi dalam proses pembelajaran. Keempat, Kebebasan : memberikan peserta didik kebebasan dalam berpendapat maupun kebebasan berfik ir untuk mengembangkan kemampuan yang dimilikinya juga pengetahuan yang lebih luas. Kelima, Kerjasama : membiasakan untuk berperilaku baik antar sesama untuk menumbuhkan rasa keakraban sehingga tolong menolong dan bekerjasama otomatis menjadi kebiasaan yang dilakukan.

\section{Daftar Rujukan}

Agil Husin Al-Munawar, Said. "Fikih Hubungan Antar Agama" Jakarta: PT Ciputat Press, 2005.

Aulia, Hilyatul. "Inklusivisme Menurut Masyarakat Muslim dan Kristen Dusun Gendeng Kel. Baciro Kec. Gondokusuman Kota Yogyakarta" Skripsi-Universitas Islam Negeri Sunan Kalijaga Yogyakarta, 2017.

B. Milies, Metther and A. Michael Hubermen. "Qualitative Data Analysis" London: Sage Publication, 1984.

Bukhori, Baidi. Toleransi terhadap Umat Kristiani Ditinjau dari Fundamentalisme Agama dan Kontrol Diri, Semarang: IAIN Walisongo Semarang, 2012. 
Falasifah Rizqia, Hasdian. "Hubungan Antara Self Maturity dan Tasamuh pada Mahasiswa Jurusan Tasawuf dan Psikoterapi Angkatan 2012 Fakultas Ushuluddin UIN Walisongo Semarang" Skripsi--Universitas Islam Negeri Walisongo Semarang, 2015.

Kuswarno, Engkus. "Fenomenologi: Metodologi Penelitian Komunikasi" Bandung: Widya Padjajaran, 2009.

Luthfi Zubaidin, Muhammad. “Implementasi At Tasamuh Ahlussunnah Wal Jama'ah Sebagai Nilai Pendidikan Karakter di Madrasah Diniyyah Darul Muttaqin Sukobendu Mantup Lamogan" Skripsi--Universitas Islam Lamongan, 2016.

Nurtaviana Arum, Erinda. "Upaya Guru Pendidikan Agama Islam dalam Menanamkan Nilai-Nilai Tasamuh di SMP Islam Ma'arif 02 Kota Malang",Jurnal Pendidikan Islam, Vol. 4, No. 8 Tahun 2019

Sugiono, "Metode Penelitian Kuantitatif Kualitatif dan R\&D” Bandung: Alfabeta, 2011.

Undang-Undang Republik Indonesia Nomor 20 Tahun 2003, Pasal 1, Ayat 1, Tentang Sistem Pendidikan Nasional. 